\title{
Evaluation of current status, threats and means of protection of heaths Arctostaphylo-Callunetum R.Tx. et Prsg 1940 in the Czerwony Bór (NE Poland)
}

\author{
Grażyna Laska \\ Department of Environmental Protection and Management, Białystok Technical University, \\ Wiejska 45a, 15-351 Białystok, Poland; e-mail: g.laska@pb.edu.pl
}

\begin{abstract}
The study was performed to identify, delimit and evaluate the current status of Arctostaphylo-Callunetum R.Tx. et Prsg 1940 heaths, as well as to point out possible threats to these communities and means of their protection. The heaths are in Czerwony Bór (PLH 200018) in Podlaskie voivodeship, NE Poland, in the area included in the Natura 2000 network. The study was performed in 2008 with the use of GPS method over the study area of 3,784.04 ha.

The area of Czerwony Bór includes 8 stands with dry heaths of Arctostaphylo-Callunetum of the total area of 21.7 ha. They are represented by typically developed and well-preserved patches of vegetation $(90 \%)$ of the area of 19.5 ha and not so well preserved patches $(10 \%)$ occupying the area of 2.2 ha. In general, their natural value in the area of study is high and the representative character, degree of preservation of the structure and functions are excellent. The main threat to the dry heaths Arctostaphylo-Callunetum in the area of Czerwony Bór comes from the forest management procedures aimed at reclamation of the area left after the army training grounds, reforestation in the form of large-area single-species forest plantations, forestation of the land that has not been forested earlier. In the areas where no plantation have been started the process of secondary succession is observed. As a result of this process heaths are replaced by forest-thicket formations. The active protection of the heaths in the area studied should include prevention of secondary succession, mowing and removal of forest-thicket formations and changes in forest management policy towards maintenance of open space by periodical removal of vegetation to bare soil.
\end{abstract}

Key words: dry heath, Natura 2000, Czerwony Bór PLH200018, nature habitats, active protection.

\section{Introduction}

The Arctostaphylo-Callunetum R.Tx. et Prsg 1940 communities found in Czerwony Bór, in Podlaskie voivodeship, have not been earlier described. These stands of dry heaths are new and for the first time reported in the expertise on nature by Łaska (2008) from the earlier designed and approved in 2011 Site of Community Importance (SCI) (based on the Act on the protection of nature) under the name of Czerwony Bór PLH200018 in Natura 2000 ecological network in Podlaskie voivodeship (www. natura2000.gdos.gov.pl).

Czerwony Bór encompasses the area earlier occupied by forest known as Red Forest whose name alluded to the domination of larch trees of brown-red bark. Later the name of the dominant larch forests was changed to Czerwony Bór. In 1926, after the total destruction of the forest by the mass appearance of Panolis flammea. The forest stand had to be removed and the area became the army training ground (Plany, 2005-2015). In the large area devoid of trees, the army systematically destroyed the upper soil layer and the vegetation cover, so that all the time it was used by the army the land was covered by the vegetation in the initial stage of development. Thanks to the use of the land by the army, some valuable non-forest habitats were preserved in the area of Czerwony Bór, such as inland dunes with psammophilous vegetation Spergulo vernalis-Corynophoretum (R.Tx. 1928) Libb. 1933, psam- 


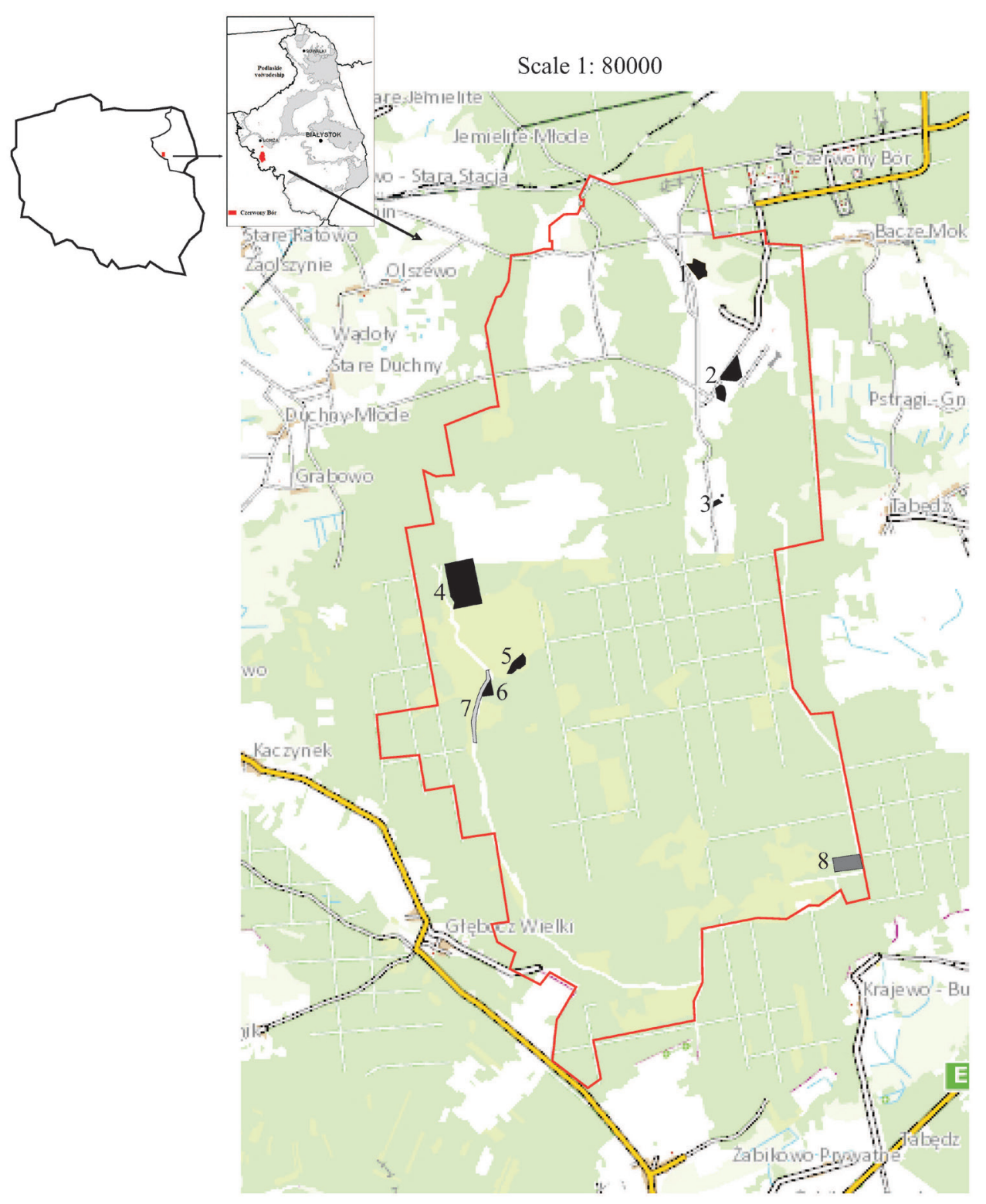

Legend:

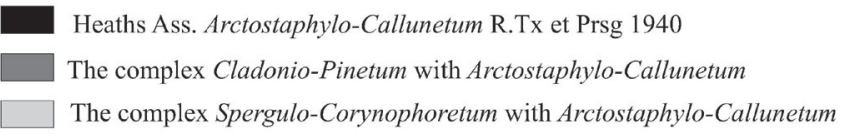

Fig. 1. Location of Arctostaphylo-Callunetum R.Tx. et Prsg 1940 heaths in the Czerwony Bór (NE Poland)

(Source base maps: www.geoportal.gov.pl, www.natura2000.gdos.gov.pl, changed)

mophilous grasslands Koelerion glaucae (Volk 1931) Klika 1935, dry heaths Arctostaphylo-Callunetum R.Tx. et Prsg 1940 and juniper formations Juniperus communis (Matuszkiewicz, 2001; Bargielski, 2007; Łaska, 2008). In 2002 the army training ground was closed down and the area was granted to the Łomża Forest Division. From that time this area has been reclaimed as forest area and the artificial tree stand renewals and reforestation started (Plany, 2005-2015). At present the specificity of the forests in the area is determined by dominant pine stands growing on 
meridionally arranged moraine hills and dunes. The aim of the study presented was identification, delimitation and evaluation of the current status of the heaths Arctostaphylo-Callunetum R.Tx. et Prsg 1940, pointing out possible threats to these communities and recommendation of active means for their functioning and protection.

\section{Study area and methods}

Czerwony Bór PLH200018 belongs to Special Areas of Conservation (SACs, or habitat sites) in NE Poland, in western part of Podlasie Province, Zambrów commune (Fig. 1). It covers the area between the geographical coordinates $53^{\circ} 03^{\prime} 31^{\prime \prime}$ and $52^{\circ} 55^{\prime} 49^{\prime \prime}$ North latitude, and $22^{\circ} 01^{\prime} 38^{\prime \prime}$ and $22^{\circ} 09^{\prime} 15^{\prime \prime}$ East longitude. According to geophysical division of the country, Czerwony Bór belongs to the macroregion Nizina Północnomazowiecka and to the mesoregion of Międzyrzecze Łomżyńskie (Kondracki, 2000).

Identification, delimitation and evaluation of the current status of dry heaths within the area of Czerwony Bór were carried out on the basis of two methods of field studies. The first one was the topographic method (observations on walking) and the second was the method of scattered points with the use of phytosociological releves (Faliński, 1990). The field studied were performed in August 2008 and also included cartographic studies with the use of GPS and phytosociological studies of plant communities. In field studies the observations on localisation, range and conditions in the heaths were recorded directly on the spot on preliminary prepared cartographic sheets. Location of particular vegetation patches were recorded on map sheets with GPS employed for detail determination of geographical coordinates. The identified and delimited locations of heaths were then mapped to give maps of dry heaths in the area of Czerwony Bór, marking their ranges and areas. Particular attention was paid to the current status of the heaths, their typical features, degree of transformation and factors threatening their existence. The sites with dry heaths in the area of Czerwony Bór were presented in the electronic form in the topographic map in the scale of 1:80000 (Fig. 1).

\section{Results}

\subsection{Identification of nature habitats in Czerwony Bór}

Czerwony Bór is an important refugium of oligo- and mesotrophic natural habitats on mineral soils. Within its area, 6 plant communities were identified, including three non-forest ones, one of thicket formations and two forest communities, listed in Enclosure I to the Habitats Direc- tive 92/43/EEC of May $21^{\text {st }}, 1992$, on protection of natural habitats and wild fauna and flora. Their areas (in ha), percentage of coverage and current status in Czerwony Bór are presented in Table 1. Syntaxonomy of particular plant communities after Matuszkiewicz (2001) is as follows:

Class (Cl.) Koelerio glaucae-Corynephoretea canescentis Klika in Klika et Novak 1941

Order (O.) Corynephoretalia canescentis R.Tx. 1937

Alliance (All.) Corynephorion canescentis Klika 1934

Association (Ass.) Spergulo vernalis-Corynophoretum (R.Tx. 1928) Libb. 1933

Alliance (All.) Koelerion glaucae (Volk 1931) Klika 1935

Cl. Nardo-Callunetea Prsg 1949

O. Calluno-Ulicetalia (Quant. 1935) R.Tx. 1937

All. Calluno-Arctostaphylion R.Tx. et Prsg 1949

Ass. Arctostaphylo-Callunetum R.Tx. et Prsg 1940

Cl. Querco-Fagetea Br.-Bl. et Vlieg. 1937

O. Fagetalia sylvaticae Pawł. in Pawł., Sokoł. et Wall 1928

All. Carpinion betuli Issl. 1931 em. Oberd. 1953

Ass. Tilio-Carpinetum Tracz. 1962

Cl. Vaccinio-Piceetea Br.-B1. 1939

O. Cladonio-Vaccinietalia Kiell.-Lund 1967

All. Dicrano-Pinion Libb. 1933

SubAll. Dicrano-Pinenion Seibert in Oberd. (ed.) 1992

Ass. Cladonio-Pinetum Juraszek 1927

Community with Juniperus communis L.

The greatest area within Czerwony Bór was occupied by juniper thickets, Juniperus communis (691.97 ha) (Table 1). Juniper thickets (code 5130) occur in the form of large patches often encompassing whole forest sections, they also occupy small area gaps in the tree stands and forest margins. They are localised mainly in the northwest, central and south-west parts of the Czerwony Bór area, on the former army training ground. In the complex with juniper thickets there are small-area patches of dry heaths Calluno-Arctostaphylion (code 4030-3) (21.70 ha) and thermophilic inland psammophilous grassland from association Koelerion glaucae (code 6120-1) (51.75 ha) and inland dunes with psammophilous grasslands Spergulo-Corynophoretum (code 2330-1) (4.31 ha). Smaller areas within Czerwony Bór are occupied with forest communities, including subcontinental oak-hornbeam forest Tilio-Carpinetum (code 9170-2) (25 ha) and inland dry pine forest Cladonio-Pinetum (code 91T0-1) (5 ha). Larger areas within Czerwony Bór are taken by the degenerative forms of fresh pine forests and mixed coniferous forests with the dominant Pinus sylvestris. 
Table 1. List of natural habitats included in Enclosure 1 to the Habitats Directive 92/43/EEC identified in the area of Czerwony Bór

Representativeness (typical character of plant communities development in a given area): A - excellent, B - good, C - significant, D - insignificant;

Relative area (area of a given community relative to the total area of this community in a given country): A $>15-100 \%, \mathrm{~B}>2-15 \%, \mathrm{C}>0-2 \%$;

State of preservation (state of preservation of structure and function of the community, possibility of its renewal): A - excellent, B - good, C - medium or impoverish state;

General evaluation (the value of a given area for protection of a given type of community): A - excellent, B - good, $\mathrm{C}-$ significant.

\begin{tabular}{|c|c|c|c|c|c|c|c|c|c|c|}
\hline \multirow{2}{*}{ Code } & \multirow{2}{*}{ Name of habitats/communities } & \multicolumn{3}{|c|}{ Area A, B, C, [ha] } & \multirow{2}{*}{$\begin{array}{l}\text { Total } \\
\text { area } \\
{[\mathrm{ha}]}\end{array}$} & \multirow{2}{*}{$\begin{array}{c}\text { Cover } \\
{[\%]}\end{array}$} & \multirow{2}{*}{$\begin{array}{l}\text { Repre- } \\
\text { sentative- } \\
\text { ness }\end{array}$} & \multirow{2}{*}{$\begin{array}{l}\text { Rel- } \\
\text { ative } \\
\text { area }\end{array}$} & \multirow{2}{*}{$\begin{array}{l}\text { State of } \\
\text { preserva- } \\
\text { tion }\end{array}$} & \multirow{2}{*}{$\begin{array}{l}\text { Gener- } \\
\text { al eval- } \\
\text { uation }\end{array}$} \\
\hline & & A & B & $\mathrm{C}$ & & & & & & \\
\hline $2330-1$ & $\begin{array}{l}\text { Ass. Spergulo vernalis- } \\
\text { Corynophoretum (R.Tx. 1928) } \\
\text { Libb. } 1933\end{array}$ & 4.11 & 0.20 & & 4.31 & 0.11 & A & $\mathrm{C}$ & A & A \\
\hline 4030-3 & $\begin{array}{l}\text { Ass. Arctostaphylo-Callunetum } \\
\text { R.Tx. et Prsg } 1940\end{array}$ & 19.50 & 2.20 & & 21.70 & 0.54 & A & $\mathrm{C}$ & A & A \\
\hline 5130 & $\begin{array}{l}\text { Formations with Juniperus } \\
\text { communis L. }\end{array}$ & 207.37 & 279.60 & 205.0 & 691.97 & 17.29 & A & $\mathrm{C}$ & B & B \\
\hline $6120-1$ & $\begin{array}{l}\text { All. Koelerion glaucae (Volk 1931) } \\
\text { Klika } 1935\end{array}$ & 3.30 & 48.45 & & 51.75 & 1.29 & A & $\mathrm{C}$ & A & A \\
\hline 9170-2 & Ass. Tilio-Carpinetum Tracz. 1962 & & 25.00 & & 25.00 & 0.62 & $\mathrm{~B}$ & $\mathrm{C}$ & $\mathrm{B}$ & B \\
\hline 91T0-1 & $\begin{array}{l}\text { Ass. Cladonio-Pinetum Juraszek } \\
1927\end{array}$ & & 5.00 & & 5.00 & 0.12 & $\mathrm{~B}$ & $\mathrm{C}$ & $\mathrm{B}$ & B \\
\hline & Total area $[\mathrm{ha}]$ & 234.28 & 360.45 & 205.0 & 799.73 & 19.97 & & & & \\
\hline
\end{tabular}

\subsection{Heaths Arctostaphylo-Callunetum R.Tx. et Prsg 1940 within Czerwony Bór}

In Czerwony Bór the plant association Arctostaphylo-Callunetum R.Tx. et Prsg 1940 is represented by subcontinental inland dry heaths of anthropogenic origin. They are found in the form of treeless shrub communities with the dominant heath Calluna vulgaris and with rich flora of moss and lichens. The communities are made of low and colourful plants, localised mainly in the north-eastern, south-eastern and western parts of the former army training ground (Fig. 1). The communities make large-area patches occupying all forest sections (section 126a) or grow in small-area patches along the forest roads, on dunes or steep slopes, where they occur in the initial stages of plant development. They grow on very poor and acidic podzolized soil of $\mathrm{pH} 4.0-5.0$, formed from loose sands and of very deep ground water table. The extreme thermal and soil conditions ensure the stability of these communities.

Within the area of Czerwony Bór, 8 sites with dry heaths Arctostaphylo-Callunetum were found, of the total area of 21.7 ha (Fig. 1). These communities were repre- sented by typically developed and excellently preserved patches (A - 90\%) occupying the area of 19.5 ha and good preserved patches $(\mathrm{B}-10 \%)$ of the area 2.2 ha (Table 2$)$. The natural value of the heaths is high and their representativeness is excellent.

Arctostaphylo-Callunetum is a community of boreal-continental type of range. Its structure is composed of two layers, that of herbs and that of moss and lichens. In the herbal layer of the coverage of $60-80 \%$ the dominant is Calluna vulgaris with Arctostaphylos uva-ursi as a subdominant. The floristic composition of differential species (Carex ericetorum, Carex praecox, Peucedanum oreosalinum, Scorzonera humilis, Arnica montana, Platanthera bifolia) and accompanying species (Hieracium pilosella, Solidago virgaurea, Geranium sanguineum, Thymus serpyllum, Trientalis europaea, Festuca ovina) are also well represented. The patches of heath, besides the species characteristic of All. Calluno-Arctostaphylion, also host the species characteristic of psammophilous grassland from the class Koelerio glaucae-Corynephoretea canescentis (Helichrysum arenarium, Corynephorus canescens) and 
Table 2. Characteristics of the locations Ass. Arctostaphylo-Callunetum R.Tx. et Prsg 1940 (4030-3) in the Czerwony Bór (for details see Figure 1)

\begin{tabular}{|c|c|c|c|c|c|c|c|}
\hline \multirow{2}{*}{$\begin{array}{l}\text { Location } \\
\text { number }\end{array}$} & \multirow{2}{*}{$\begin{array}{c}\text { Code } \\
\text { habitats }\end{array}$} & \multirow{2}{*}{$\begin{array}{l}\text { Forest } \\
\text { section }\end{array}$} & \multirow{2}{*}{$\begin{array}{l}\text { Location } \\
\text { Forestry }\end{array}$} & \multicolumn{2}{|c|}{ Geographical coordinates } & \multirow{2}{*}{$\begin{array}{c}\text { Area } \\
\text { [ha] }\end{array}$} & \multirow{2}{*}{$\begin{array}{c}\text { State of } \\
\text { preservation }\end{array}$} \\
\hline & & & & N latitude & E longitude & & \\
\hline 1. & $4030-3$ & $42 \mathrm{a}$ & Czerwony Bór & 530202.5 & 220606.0 & 0.5 & $\mathrm{~B}$ \\
\hline 2. & $4030-3$ & $64 d / 74 a$ & Czerwony Bór & 530115.6 & 220611.8 & 1.0 & $\mathrm{~B}$ \\
\hline 3. & $4030-3$ & $102 b$ & Czerwony Bór & 530018.8 & 220601.9 & 0.2 & B \\
\hline 4. & $4030-3$ & $126 \mathrm{a}$ & Czerwony Bór & 525950.8 & 220253.8 & 17.5 & A \\
\hline \multirow[t]{2}{*}{5.} & $4030-3$ & $155 \mathrm{~b} / 156 \mathrm{c}^{*}$ & Czerwony Bór & 525915.6 & 220336.5 & 1.0 & A \\
\hline & & & & 525906.9 & 220316.8 & & \\
\hline 6. & $4030-3$ & $157 \mathrm{f}$ & Czerwony Bór & 525903.3 & 220312.7 & 0.5 & A \\
\hline \multirow[t]{3}{*}{7.} & $2330-1 /$ & $157 b$ & Czerwony Bór & 525908.7 & 220312.1 & & \\
\hline & $4030-3$ & $172 \mathrm{c}$ & Tabędz & 525854.4 & 220302.2 & 0.5 & B \\
\hline & & $173 c$ & Tabędz & 525840.7 & 220300.4 & & \\
\hline 8. & $91 \mathrm{~T} 0-1 /$ & $244 b *$ & Tabędz & 525741.6 & 220732.8 & 0.5 & A \\
\hline \multirow{2}{*}{\multicolumn{6}{|c|}{ Total area [ha] / State of preservation }} & 19.5 & A - excellent \\
\hline & & & & & & 2.2 & B - good \\
\hline
\end{tabular}

* The geographical coordinates after Wolkowycki 2008 (unpublished)

thermophilic herbal communities from the class Trifolio-Geranietea sanguinei (Digitalis grandiflora, Inula hirta, Peucedanum cervaria). The layer of moss and lichens is rich, $100 \%$ coverage (Pleurozium schreberi, Hylocomium splendens, Dicranum scoparium, Dicranum polysetum, Polytrichum piliferum, Pohlia nutans, Hypnum jutlandicum, Ceratodon purpureus) and lichens (Cladonia mitis, Cladonia arbuscula, Cladonia chlorophaea, Cladonia furcata). The patches of heath may also sporadically show some trees and bushes, including Pinus sylvestris, Betula pendula, Populus tremula and Juniperus communis. The height of heaths varies from a few $\mathrm{cm}$ to $25-30 \mathrm{~cm}$.

\section{Possible threats and protective measures - discussion}

The heaths of the type Arctostaphylo-Callunetum occur at dispersed sites, mainly in north-eastern and central-eastern Poland (Ciosek, 2000; Rakowski, 2003). They are composed of subcontinental-subboreal heath type vegetation sustained at these localities only thanks to the specific habitat conditions and human activity (Britton et al., 2003; Holden et al., 2007; Albert et al., 2011, 2012; Kongstad et al., 2012). That is why they are classified as vulnerable communities and need active protection measures (Britton et al., 2000; Hulme et al., 2002; Pakeman et al., 2003; Littlewood et al., 2006a; Mitchell et al., 2008a; Pywell et al., 2011; Quin et al., 2014). Their floristic composition includes species (Arctostaphylos uva-ursi, Lycopodium clavatum, Botrychium lunaria) that are under legal protection.

Dry heaths Calluno-Arctostaphylion were maintained in the area of Czerwony Bór only thanks to the former use of the area as an army training ground. The army systematically destroyed the soil surface and vegetation cover, so that the initial stages of plant development did not have a chance to develop further. In 2002 the army training ground was granted to the Łomża Forest Division and the process of planned management started, including artificial forestation in the form of large-area monocultural forest crops and plantations. At present Czerwony Bór is within the Łomża Forest Division, District Zambrów II, Forestry Czerwony Bór and Tabędz of the total area of Zambrów II (6848.1805 ha), in Czerwony Bór area forests take 64.4\%, and non-forest grounds take $37.6 \%$. From among forest area, $98.6 \%$ are the forests of economical use subjected to forest management control (3,984.03 ha), the dominant type of habitat is that of fresh mixed forest $(52.3 \%)$ and fresh forest $(39.8 \%)$ with the dominant Pinus sylvestris (Plany, 2005-2015). The above mentioned types of management in the area left after the army training ground brings threat to further existence of the heaths. In the are- 
as with no artificial forestation but also with no measures aimed at maintenance of open space, the secondary succession is observed, leading to spontaneous phase out of the heaths by thickets formations or forest communities made by pioneer species (Betula pendula, Populus tremula, Pinus sylvestris, Juniperus communis). The patches of heaths are often accompanied by thickest of Sarothamnus scoparius, which is geographically foreign to Podlaskie Province and whose expansion together with eutrophication of habitats also pose threats to the functioning of the communities. Eutrophication of the habitats and changes in the edaphic and luminous conditions are conducive to transformation of the heaths towards mesotrophic thermophilic herbal communities and later to thickest and forest communities (Alonso et al., 2001; Littlewood et al., 2006b; Britton \& Fisher, 2008; Sowerby et al., 2008).

The active protection of the heaths in Czerwony Bór should include the means preventing the secondary succession such as removal of trees and bushes as well as periodical mowing, but first of all the change in methods of forest management. Inhibition of secondary succession will provide the access of light desired by the heath and will restrict accumulation of non-decomposed organic matter leading to increased trophy of the habitat (Britton et al., 2003; Rinnana et al., 2007; Mitchell et al., 2008b; Nielsen et al., 2009; Kongstad et al., 2012). The measures within the forest management in the area should be aimed at preservation of open space land by periodical removal of vegetation to bare soil.

\section{References}

Albert K.R., Mikkelsen T.N., Michelsen A., Ro-Poulsen H. \& Linden L., 2011, Interactive effects of drought, elevated $\mathrm{CO}_{2}$ and warming on photosynthetic capacity and photosystem performance in temperate heath plants, Journal Plant Physiology, 168: 1550-1561.

Albert K.R., Kongstad J., Schmidt I.K., Ro-Poulsen H., Mikkelsen T.N., Michelsen A., Linden L. \& Beier C., 2012, Temperate heath plant response to dry conditions depends on growth strategy and less on physiology, Acta Oecologica, 45: 79-87, dx.doi.org/10.1016/j.actao.2012.09.003.

Alonso I., Hartley S.E. \& Thurlow M., 2001, Competition between heather and grasses on Scottish moorlands: interacting effects of nutrient enrichment and grazing regime, Journal of Vegetation Science, 12: 249-260.

Bargielski J., 2007, Program Ochrony Przyrody: Referat $\mathrm{w}$ sprawie aktualizacji programu ochrony przyrody [Nature Protection Program: A paper on the update of nature protection], Nadleśnictwo Łomża [Forestry Division], Łomża: 1-12.
Britton A.J. \& Fisher J.M., 2008, Growth responses of low-alpine dwarf-shrub heath species to nitrogen deposition and management, Environmental Pollution, 153: 564-573, doi:10.1016/j.envpol.2007.09.022.

Britton A.J., Marrs R.H., Carey P.D. \& Pakeman R.J., 2000, Comparison of techniques to increase Calluna vulgaris cover on heathland invaded by grasses in Breckland, south east England, Biological Conservation, 95: 227-232.

Britton A.J., Marrs R., Pakeman R. \& Carey P., 2003, The influence of soil-type, drought and nitrogen addition on interactions between Calluna vulgaris and Deschampsia flexuosa: implications for heathland regeneration, Plant Ecology, 166: 93-105.

Ciosek M.T., 2000, Mącznica lekarska Arctosaphylos uva-ursi (L.) Spreng. i wrzosowiska macznicowe Arctostaphylo-Callunetum R. Tx. et Prsg. 1949 w Polsce środkowo-wschodniej na tle ich zrożnicowania w Polsce [Arctostaphylos uva-ursi (L.) Spreng. bearberry and moorland Arctostaphylo-Callunetum R. Tx. et Prsg. 1949 in the central-eastern Poland against their differentiation in Poland], Rozprawy Naukowe Akademii Podlaskiej 65, Siedlce: 1-82.

Faliński J.B., 1990, Kartografia Geobotaniczna, Cz. 2 Kartografia fitosocjologiczna [Geobotanical cartography, Vol. 2 Phytosociological cartography], PPWK, Warszawa-Wrocław.

Holden J., Shotbolt L., Bonn A., Burt T.P., Chapman P.J., Dougill A.J., Fraser E.D.G., Hubacek K., Irvine B., Kirkby M.J., Reed M.S., Prell C., Stagl S., Stringer L.C., Turner A. \& Worrall F., 2007, Environmental change in moorland landscapes, Earth-Science Reviews, 82: 75-100.

Hulme P.D., Merrell B.G., Torvell L., Fisher J.M., Small J.L. \& Pakeman R.J., 2002, Rehabilitation of degraded Calluna vulgaris (L.) Hull - dominated wet heath by controlled sheep grazing, Biological Conservation, 107: 351-363.

Kondracki J., 2000, Geografia regionalna Polski [Polish Regional Geography], PWN, Warszawa.

Kongstad J., Schmidt I.K., Riis-Nielsen T., Arndal M.F., Mikkelsen T.N. \& Beier C., 2012, High resilience in heathland plants to changes in temperature, drought, and $\mathrm{CO}_{2}$ in combination: results from the CLIMAITE experiment, Ecosystems, 15: 269-283.

Littlewood N.A., Pakeman R.J. \& Woodin S.J., 2006a, A field assessment of the success of moorland restoration in the rehabilitation of whole plant assemblages, Applied Vegetation Science, 9: 295-306.

Littlewood N.A., Pakeman R.J. \& Woodin S.J., 2006b, The response of plant and insect assemblages to the loss of Calluna vulgaris from upland vegetation, Biological Conservation, 128: 335-345. 
Łaska G., 2008, Raport z wykonanej ekspertyzy projektu obszaru sieci natura $2000 \mathrm{w}$ województwie podlaskim: Czerwony Bór, Zielona Puszcza Kurpiowska, Ostoja Knyszyńska i okolice Suraża [The report of the expertise made the project area network Natura 2000 in Podlaskie Province: Red Forest, Green Forest Kurpiowska, Refuge Knyszyńska and around Suraż], Ministerstwo Środowiska, Białystok.

Matuszkiewicz W., 2001, Przewodnik do oznaczania zbiorowisk roślinnych Polski [A guide to determine plant communities of Poland], PWN, Warszawa.

Mitchell R.J., Rose R.J. \& Palmer S.C.F., 2008a, The effect of restoration techniques on non-target species: case studies in moorland ecosystems, Applied Vegetation Science, 12: 81-91.

Mitchell R.J., Rose R.J. \& Palmer S.C.F., 2008b, Restoration of Calluna vulgaris on grass -dominated moorlands: the importance of disturbance, grazing and seeding, Biological Conservation, 141: 2100-2111.

Nielsen P.L., Andresen L.C., Michelsen A., Schmidt I.K., Kongstad J., 2009, Seasonal variations and effects of nutrient applications on $\mathrm{N}$ and $\mathrm{P}$ and microbial biomass under two temperate heathland plants, Applied Soil Ecology, 42: 279-287.

Pakeman R.J., Hulme P.D., Torvell L. \& Fisher J.M., 2003, Rehabilitation of degraded dry heather [Calluna vulgaris (L.) Hull] moorland by controlled sheep grazing, Biological Conservation, 114: 389-400.

Plany Urządzania Gospodarstwa Leśnego Nadleśnictwa Łomża na okres 01.01.2005-31.12.2015 [Plans of For- est Management in Łomża Forest Division for 20052015], Nadleśnictwo Łomża [Forest Division], Łomża. Pywell R.F., Meek W.R., Webb N.R., Putwain P.D. \& Bullock J.M., 2011, Long-term heathland restoration on former grassland: the results of a 17-year experiment, Biological Conservation, 144: 1602-1609.

Quin S.L.O., Artz R.R.E., Coupar A.M., Littlewood N.A. \& Woodin S.J., 2014, Restoration of upland heath from a graminoid- to a Calluna vulgaris - dominated community provides a carbon benefit, Agriculture, Ecosystems and Environment, 185: 133-143, dx.doi. org/10.1016/j.agee [Accessed 2013.12.022].

Rakowski W., 2003, Zbiorowiska wrzosowisk z rzędu Vaccinio myrtilli-Genistetalia pilosae Schubert 1960 ex Passarge 1964 w Wielkopolsce [Heathland communities in order Vaccinio myrtilli-Genistetalia pilosae Schubert Passarge 1960 ex 1964 in the Wielkopolska], Badania Fizjograficzne nad Polską Zachodnią, Ser. B, 52: 27-64.

Rinnana R., Michelsen A., Baatha E. \& Jonasson S., 2007, Mineralization and carbon turnover in subarctic heath soil as affected by warming and additional litter, Soil Biology and Biochemistry, 39: 3014-3023.

Sowerby A., Emmett B.A., Tietema A. \& Beier C., 2008, Contrasting effects of repeated summer drough on soil carbon efflux in hydric and mesic heathland soils, Global Change Biology, 14: 2388-2404.

www.geportal.gov.pl

www.natura2000.gdos.gov.pl 